\title{
Electrocatalytic Behavior of Mediators during Anodic Oxidation of Tartaric Acid at Platinum Electrodes
}

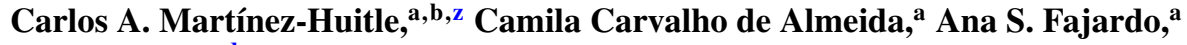 \\ Sergio Ferro, ${ }^{c, d}$ and Achille De Battisti ${ }^{\mathrm{c}}$ \\ ${ }^{a}$ Institute of Chemistry, Federal University of Federal do Rio Grande do Norte, Lagoa Nova CEP 59078-970 - Natal, \\ $R N$, Brazil \\ ${ }^{b}$ Unesp, National Institute for Alternative Technologies of Detection, Toxicological Evaluation and Removal of \\ Micropollutants and Radioactives (INCT-DATREM), Institute of Chemistry, 14800-900 Araraquara (SP), Brazil \\ ${ }^{c}$ Dipartimento di Scienze Chimiche e Farmaceutiche, Universita degli Studi di Ferrara, 44121 Ferrara, Italy
}

\begin{abstract}
The effect of the nature and concentration of different halide salts $(\mathrm{NaBr}, \mathrm{NaCl}$ and $\mathrm{NaF})$ was followed by electrochemical measurements in an alkaline media. Based on the interesting results that were obtained, the electrochemical oxidation (EO) of tartaric acid (TA) with Pt electrodes was performed in the absence and presence of those substances, in order to verify their influence in indirect electrocatalytic mechanisms. A slow EO was observed in the absence of mediators. Conversely, with halide salts, the rate of the electrochemical incineration was significantly enhanced in the following order $\mathrm{Cl}^{-}<\mathrm{Br}^{-}<\mathrm{F}^{-}$. The rate of the mediated process was practically independent of applied current density $\left(30\right.$ and $\left.60 \mathrm{~mA} \mathrm{~cm}{ }^{-2}\right)$. Energy efficiency and energy consumption parameters were estimated, as well as the by-products were detected by GC/MS technique.
\end{abstract}

(C) 2017 The Electrochemical Society. [DOI: 10.1149/2.0191713jes] All rights reserved.

Manuscript submitted July 20, 2017; revised manuscript received September 12, 2017. Published September 22, 2017.

Since the early eighties, the electrochemical performance of organic compounds has been widely documented in literature, taking into account reaction kinetics, mechanistic pathways, electrosynthesis as well as oxidation. ${ }^{1,2}$

Specially, the electrochemical oxidation (EO) has attracted much interest due to its features. This process is considered an environmental benign technology able to mineralize completely non-biodegradable organic matter, using the electron as a clean reagent and working at ambient temperature and pressure. Simple equipment is employed (with or without an ionic membrane, with or without recycling, with bi- or three-dimensional electrodes), having an easy operation system. ${ }^{3}$

The degradation of the pollutants can take place through two different mechanisms by direct electrochemical oxidation (DEO) or by indirect electrochemical oxidation (IEO) ${ }^{2,4-12}$ The DEO of contaminants occurs at the anode surface. In IEO, the oxidants are electrochemically generated, such as the highly reactive form of silver $\left(\mathrm{Ag}^{2+}\right)$, CerOX process, $\mathrm{Cl}_{2}, \mathrm{HClO}, \mathrm{ClO}^{-},{ }^{\bullet} \mathrm{OH}, \mathrm{H}_{2} \mathrm{O}_{2}, \mathrm{O}_{3}$ or $\mathrm{S}_{2} \mathrm{O}_{8}^{2-}$ and then the pollutants are destroyed in the bulk solution. ${ }^{2,13-15} \mathrm{CerOx}$ technology is based on the cerium(IV)-mediated oxidation of organic compounds. The CerOx process utilizes an electrochemical reaction to produce (and regenerate) the active, waste-destroying reagent. ${ }^{13}$ Meanwhile, chloride mediation is of particular interest, due to its effective action. The ever-presence of chloride ions in several wastewaters and also natural waters makes the contribution of active $\mathrm{Cl}_{2}$ inevitable. Under certain conditions, the reaction of this substance with organics may promote the formation of organic chlorinated compounds, which are common intermediates in the chloride-mediated oxidation of aromatic substances, ${ }^{16}$ and also may yield chloroform by the oxidation of aliphatic molecules. ${ }^{8}$ Although there are disadvantages in the electrochemical process, this technique can lead to considerable improvements in the removal of pollutants depending on the care with the control variables. ${ }^{6}$ Beyond $\mathrm{Cl}^{-}$, the presence of other halogen ions, such as $\mathrm{Br}^{-}$and $\mathrm{F}^{-}$, have already been studied in the $\mathrm{EO}$ of organic compounds at different anode materials (Pt, Ti/Pt and BDD) ${ }^{6,17,18}$ According to those previous studies, the participation of halogen salts in the IEO of organic pollutants is interesting in order to understand the pathways of the electrocatalytic process. In the research of electrochemical incineration of oxalic acid (OA) in an alkaline media at $\mathrm{Pt}$ or $\mathrm{Ti} / \mathrm{Pt}$ anodes, ${ }^{6}$ three mediators were tested $(\mathrm{NaBr}, \mathrm{NaCl}$ and $\mathrm{NaF}$ ). The optimum incineration results were obtained at the Pt electrode using the $\mathrm{NaF}$ salt, supporting the idea that the interaction of

${ }^{\mathrm{d}}$ Present address: Ecas4 Australia Pty Ltd, Unit 8/1 London Road, Mile End South, SA 5031, Australia.

zE-mail: carlosmh@quimica.ufrn.br organic substrate with the electrode surface plays a key role in the electrochemical process.

Therefore, this work aims to extend the research to the anodic oxidation of tartaric acid TA (a more complex molecule than OA) in the presence of three different halides ions $\left(\mathrm{Br}^{-}, \mathrm{Cl}^{-}, \mathrm{F}^{-}\right)$, to focus on volume and anode surface effects in indirect electrochemical incineration. Hence, the influence of some parameters such as halogen salt concentration and current density $(j)$.

\section{Experimental}

Synthetic solution and reagents.-Fresh $0.1 \mathrm{M}$ solutions of TA (Fluka, dihydrate salt) were prepared in $0.25 \mathrm{M} \mathrm{NaOH}$ (Riedel-de-Haën) plus $0.5 \mathrm{M} \mathrm{Na}_{2} \mathrm{SO}_{4}$ (Baker analyzed), using distilled water. $\mathrm{NaOH}$ and $\mathrm{Na}_{2} \mathrm{SO}_{4}$ were applied to further increase the electrolyte conductivity. $\mathrm{NaCl}, \mathrm{NaBr}$ and $\mathrm{NaF}$ (Fluka) were used as received, without any further purification.

Electrochemical measurements.-Electrochemical measurements were performed with an Autolab model PGSTAT320N (Metrohm) using a conventional three-electrode system. Pt with an exposed geometric area of ca. $0.75 \mathrm{~cm}^{2}$ was used as the working electrode, while a Pt wire and an $\mathrm{Ag} / \mathrm{AgCl}(3 \mathrm{M} \mathrm{KCl})$ electrode were employed as auxiliary and reference electrodes, respectively. Quasisteady polarization curves were carried out at a scan rate of $5 \mathrm{mV} \mathrm{s}^{-1}$ and with a $0.45 \mathrm{mV}$ step potential, in solutions of halides at different concentrations, using $\mathrm{Na}_{2} \mathrm{SO}_{4}$ plus $\mathrm{NaOH}$ as supporting electrolyte. Experiments were performed between 0.7 and $2.0 \mathrm{~V}$.

Electrochemical system.-Bulk electrolyzes were carried out in a single-body thermostated $\left(\sim 25^{\circ} \mathrm{C}\right)$ pyrex glass cell of $250 \mathrm{~mL}$, under galvanostatic conditions. The test solution volume was $200 \mathrm{~mL}$ and it was vigorously stirred by means of a magnetic stirrer. The anode was a Pt grid with a geometrical area of $15 \mathrm{~cm}^{2}$ and the cathode was a larger platinum grid, both connected to a power supply MINIPA $3305 \mathrm{i}$, testing 30 and $60 \mathrm{~mA} \mathrm{~cm}^{-2}$ of current density.

Analytical techniques.-Total organic carbon (TOC) was determined with a Shimadzu 5000A Analyzer. The chemical oxygen demand (COD) was determined according to the method described by Jirka and Carter. ${ }^{19}$ Intermediates generated during the process were followed by a GC Varian Star 3400CX, with a column MS5 of 30 meters, $0.25 \mathrm{~mm}$ of diameter and $0.25 \mathrm{~mm}$ of film thickness connected to MS Varian Star GC/MS 2000. Samples were treated by 
solid phase micro-extraction (SPME) ${ }^{20}$ before GC/MS analysis. $\mathrm{pH}$ was also monitored.

The efficiency parameters of anodic oxidation taking into account in this work were instantaneous current efficiency (ICE) (Eq. 1), total current efficiency (TCE) (Eq. 2) and energy consumption (EC) (Eq. 3). ${ }^{2,6,8,9,12-15}$

$$
\begin{gathered}
I C E(\%)=F V\left(\frac{\left[(C O D)_{t}-(C O D)_{t+\Delta t}\right]}{8 I \Delta t}\right) \\
T C E(\%)=F V\left(\frac{\Delta C O D}{8 I \Delta t}\right) \\
E C(k W h / k g C O D)=\frac{E_{\text {cell }} I t}{\Delta C O D V}
\end{gathered}
$$

where, $F$ corresponds to the Faraday constant $\left(96487 \mathrm{C} \mathrm{mol}^{-1}\right), V$ to the solution volume (L), 8 to the equivalent mass of oxygen $\left(\mathrm{g} \mathrm{eq}^{-1}\right)$, $I$ to the current intensity (A), $E_{\text {cell }}$ to the average of the applied voltage on the cell, $t$ expresses the electrolysis time (s for ICE or $\mathrm{h}$ for EC), $C O D_{t}$ and $C O D_{t+\Delta t}$ to the chemical oxygen demand at times $t$ and $t+\Delta t\left(\mathrm{gO}_{2} \mathrm{~L}^{-1}\right)$ and $\Delta t$ is the difference in COD $\left(\mathrm{gO}_{2} \mathrm{~L}^{-1}\right)$.

\section{Results and Discussion}

Electrochemical measurements.-Quasi-steady polarization curves were recorded in background solutions containing $0.25 \mathrm{M}$ $\mathrm{NaOH}$ and $0.5 \mathrm{M} \mathrm{Na}_{2} \mathrm{SO}_{4}$, in the absence and in the presence of different concentrations of sodium halides $\left(\mathrm{Cl}^{-}, \mathrm{Br}^{-}\right.$and $\left.\mathrm{F}^{-}\right)$. The effect of the nature and concentration of these salts was evaluated on the oxygen evolution reaction (OER).

The data achieved for each halogen salt are depicted in Figure 1. Regarding the results with $\mathrm{NaCl}(0.001 \mathrm{M}-2.0 \mathrm{M})$, in Figure 1a, it is possible to observe that its introduction into the system led to the onset of the OER shifts from 1.2 to $1.65 \mathrm{~V}$ vs $\mathrm{Ag} / \mathrm{AgCl}$ and continue to higher potentials up to the introduction of $0.5 \mathrm{M} \mathrm{NaCl}$. At this point the number of hydroxyl radicals may promote a quick incineration of the pollutant aid by the coexistence of oxychloro-radicals favoring the electrochemical oxidation instead of the OER. ${ }^{6,8}$ However, for higher concentration values $(0.8$ and $2.0 \mathrm{M})$, a reverse of the trend is observed. This situation may be due to the increase of the importance of $\mathrm{Cl}_{2} / \mathrm{H}_{2} \mathrm{O}$ system as a potentiostatic buffer. ${ }^{6,21-23}$

In the case of $\mathrm{NaBr}$ (Figure $1 \mathrm{~b})$, low concentrations $(<0.01 \mathrm{M})$ led to a less pronounced shift of the polarization curves to the positive direction when compared to the experiments with $\mathrm{NaCl}$. Moreover, above $0.01 \mathrm{M} \mathrm{NaBr}$, it seems that the anode potential is buffered by the halide electroactivity considering the generation of bromo- and oxybromo-species at the anode surface, as already demonstrated by Martínez-Huitle et al. ${ }^{6}$

In Figure 1c, regardless the concentration of $\mathrm{NaF}$ used, the shift of the OER was always toward positive values, revealing that this halide ion is not as electroactive as the previous two species.

According to the remarkable results achieved, it is proposed to be studied the role of $\mathrm{Cl}^{-}, \mathrm{Br}^{-}$and $\mathrm{F}^{-}$during the $\mathrm{EO}$ of organic molecules in order to clarify the improvements in degradation efficiency.

Anodic oxidation.-Anodic oxidation experiments of TA were performed in absence and presence of sodium salts at different applied $j$ (30 and $60 \mathrm{~mA} \mathrm{~cm}^{-2}$ ), as depicted in Figure 2. In the absence of mediators, only a slight mineralization degree of TA is reached with less than $10 \%$ of final TOC removed. This behavior was also confirmed when the TA concentration was monitored (inset of Figure 2a), showing that the highest removal $(\sim 15 \%)$ was achieved after $75 \mathrm{Ah} \mathrm{L}^{-1}$ of electrical charge passed. This behavior may be due to specific interactions of the TA molecule toward the electrode surface. ${ }^{5,10}$ Yan et al. ${ }^{24}$ evaluated the adsorption of TA on $\mathrm{Cu}(111)$ by electrochemical scanning tunneling microscopy in aqueous solution, being observed that both $(R, R)$-TA and $(S, S)$-TA form ordered adlayer
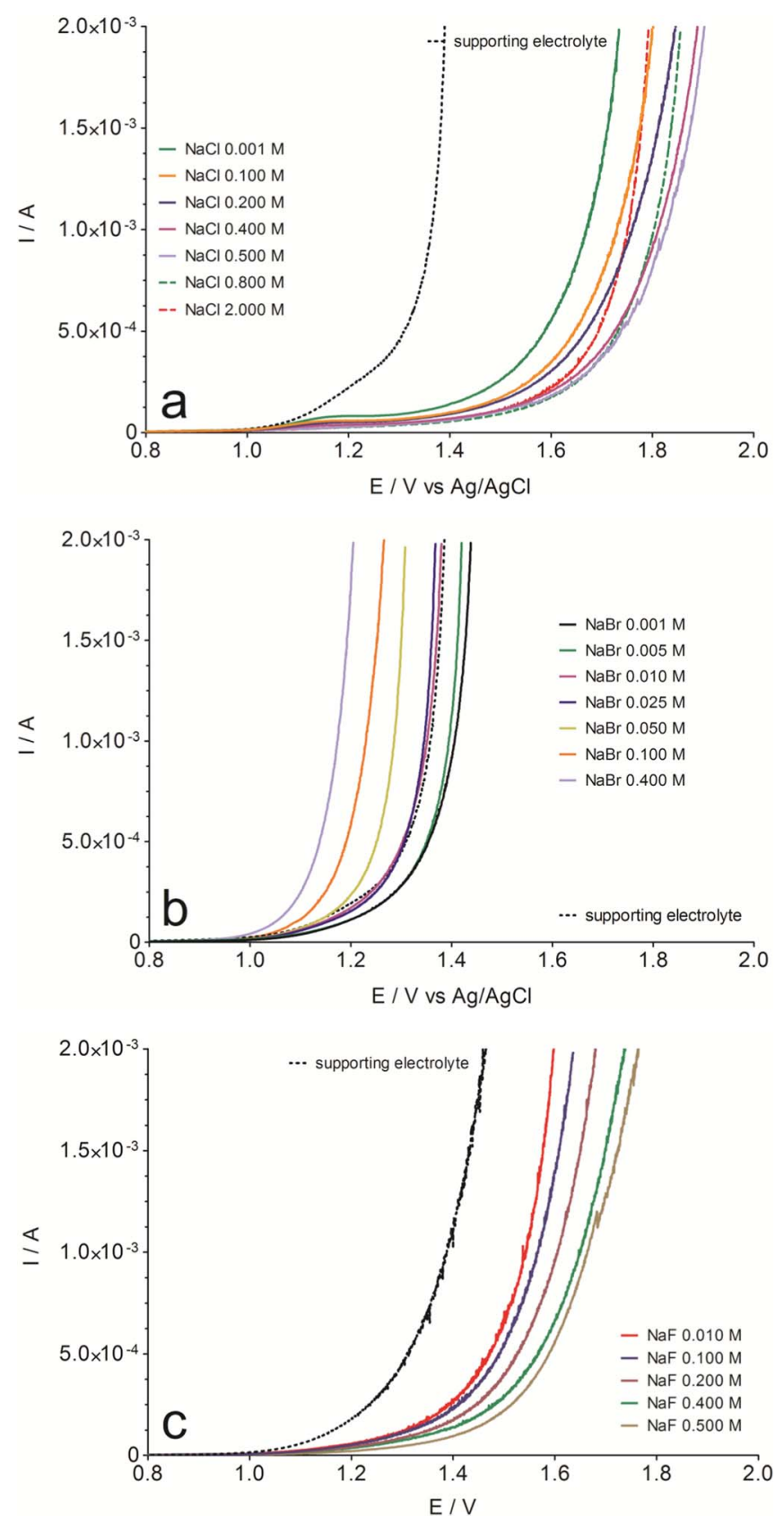

Figure 1. Current-potential curves for the Pt electrode in the presence of different amounts of (a) $\mathrm{NaCl}$, (b) $\mathrm{NaBr}$ and (c) $\mathrm{NaF}$ in solution by using 0.25 $\mathrm{M} \mathrm{NaOH}+0.5 \mathrm{M} \mathrm{Na}_{2} \mathrm{SO}_{4}$ as supporting electrolyte at scan rate of $5 \mathrm{mV} \mathrm{s}^{-1}$.

structures in a $(4 \times 4)$ symmetry on the $\mathrm{Cu}(111)$ surface which is an indication that particular TA orientations/interactions are feasible on Pt surface. ${ }^{24}$ Experimental and theoretical methods were carried out with $\mathrm{Ni}(110)$ using ultra-high vacuum surface characterization techniques by Humblot et al. ${ }^{25}$ being suggested that the adsorption of $(R, R)$-TA molecules is attained due to the enantioselective of catalysts favoring a chiral reconstruction of the substrate. ${ }^{25}$ These molecules can also produce three distinct ordered structures on the Ni(111) surface at different temperatures. ${ }^{26}$ Moreover, Hazzazi et al. ${ }^{27}$ revealed that the presence of terraces, steps and kinks on the Pt surface favor the adsorption of $(R, R)-\mathrm{TA} .^{27}$

Therefore, it seems that the adsorption interactions will depend on the metal and the position of the hydroxyl group on the TA molecule. In this work, one can hypothesize that TA structure and geometry 


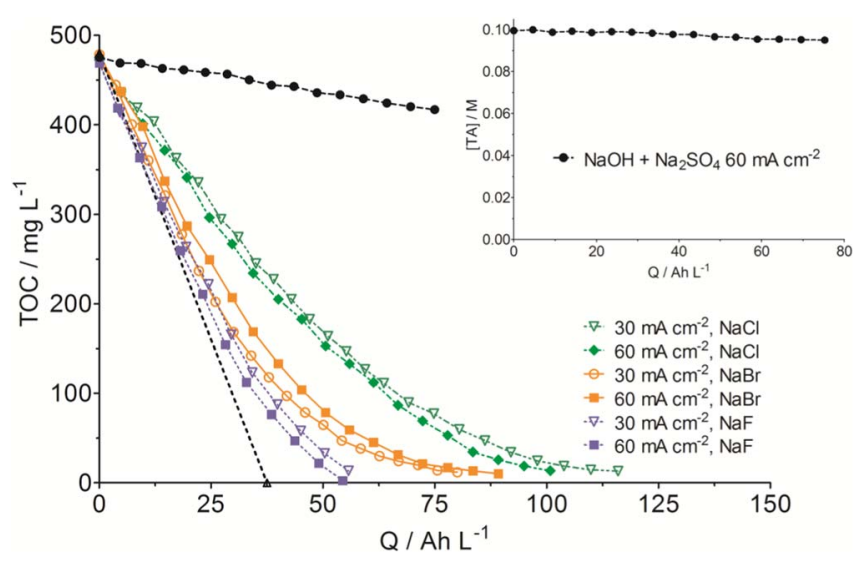

Figure 2. TOC removal vs specific charge passed (Q) in absence and presence of halides in solution at 30 and $60 \mathrm{~mA} \mathrm{~cm}^{-2}$. Inset: Concentration of TA as a function of the specific charge passed. Operating conditions: Supporting electrolyte $\left(0.25 \mathrm{M} \mathrm{NaOH}+0.5 \mathrm{M} \mathrm{Na}_{2} \mathrm{SO}_{4}\right)$ and $0.1 \mathrm{M} \mathrm{TA}$.

promote the adsorption phenomena due to the active sites at the $\mathrm{PtOx}$ surface, limiting its complete removal.

The anodic oxidation of TA, in the presence of halide salts, presented a different trend in the mineralization of the organic matter when compared to the experiment with no mediator, as it can be observed in Figure 2. Regardless the mediator applied to the system, the pollutant is almost complete mineralized with different degradation rates. The presence of $5 \mathrm{~g} \mathrm{~L}^{-1} \mathrm{NaCl}$ required $100-120 \mathrm{Ah} \mathrm{L}^{-1}$ of electrical charge passed to incinerate the TA. The elimination rate is similar independently of the applied $j$. This result is comparable to those obtained in previous investigations for oxalic acid, ${ }^{6}$ glucose ${ }^{11}$ and 2-napthol oxidation. ${ }^{12}$ The introduction of $5 \mathrm{~g} \mathrm{~L}^{-1} \mathrm{NaBr}$ was more effective than $\mathrm{NaCl}$, allowing a decrease in the electrical charge passed from $100-120$ to $80-88 \mathrm{Ah} \mathrm{L}^{-1}$, and consequently a reduction in the treatment time was attained. In this case, the elimination rate was slightly superior at $30 \mathrm{~mA} \mathrm{~cm}{ }^{-2}$ than at $60 \mathrm{~mA} \mathrm{~cm}^{-2}$. This can be due to the secondary reactions, mainly the gas evolution, favored at higher $j .^{2,28}$ The experiments with $\mathrm{NaF}$ showed that this mediator led to the quickest oxidation (55-56 $\mathrm{Ah} \mathrm{L}^{-1}$ ) of the TA independently of the applied $j$.

Analyzing the results reported in Figures 1 and 2, those showed that the presence of mediators favored notably the abatement of the organic pollutant. Halide salts inhibited the adsorption of the contaminant on the electrode surface as referred by da Silva et al. ${ }^{5}$ The electrochemical incineration was accelerated by halide ions in the following order: $\mathrm{Cl}^{-}<\mathrm{Br}^{-}<\mathrm{F}^{-}$. Probably, the $\mathrm{F}^{-}$anion has the role to change the stoichiometry and microstructure of the oxide film, inhibiting the $\mathrm{OER}^{6}$ and consequently favors the rapid electrochemical incineration of TA as well as the electrochemical production of $F_{2}$ that is also considered a good oxidant. ${ }^{29}$ In the case of $\mathrm{Br}^{-}$ion, the main factor seems to be the electrogeneration of strong oxidants (Br-based oxy-anions) through bulk electrolysis. ${ }^{2,13}$ These Br-based oxidants react rapidly with the organic matter in solution, promoting its complete degradation. In fact, as observed in Figure $1 \mathrm{~b}$, lower $\mathrm{NaBr}$ concentra- tions are necessary to inhibit the OER as well as to favor the $\mathrm{Br} / \mathrm{H}_{2} \mathrm{O}$ system to promote the production of oxidants in solution. The effect obtained with $\mathrm{Cl}^{-}$appears as a mixture of the two former situations; i.e. with possible electrogeneration of strong oxidants, but also with changes in the electrode film properties, which makes it less active toward OER. ${ }^{2,8,11-14}$ The concentration of $\mathrm{NaCl}$ in solution plays an important role in the process because it enhances the production of oxidants and/or when the solution is saturated, the chlorine evolution reaction can be mainly preferred (see, Figure 1a).

The formation of intermediates during the TA oxidation, in the presence of each mediator, was followed by GS/MS analysis. When $\mathrm{NaCl}$ was used, traces of organochlorinated compounds $(<0.15 \mathrm{mg}$ $\mathrm{L}^{-1}$ ) were detected, which disappeared during the electrolysis. Chloroform was also identified. This substance was not considered an environmental problem since it can be easily adsorbed on active carbon and destroyed by hydrolysis in basic medium.

Regarding the experiments with $\mathrm{NaBr}$, the formation of halide intermediates was not observed, but a small amount of OA was detected during the process. Through Figure 2, it was possible to verify the complete elimination of organic matter, confirming that both organic compounds (TA and OA) were totally oxidized at the final stages of the process due to the participation of the strong oxidants formed in solution. These results are in agreement with the previously reported by Noyes ${ }^{30}$ where different reactions involving the oxidation of the organic substrates by acidic bromate were studied. In the case of TA oxidation in the presence of $\mathrm{NaF}$, there was no detection of intermediates formation.

Through the IEO work, it was verified that the elimination rate mainly depended on the mediator and the specific charge passed. In this way, ICE, TCE and EC values have been estimated (Table I). As it can be observed, the experiment only containing the support electrolyte $\left(\mathrm{NaOH}+\mathrm{Na}_{2} \mathrm{SO}_{4}\right)$ led to the poorer current efficiencies (ICE $-7.4 \%$ and TCE $-5.5 \%$ ) and to the highest energy consumption (207.5 kWh kg COD $\left.{ }^{-1}\right)$. The current efficiency values obtained with mediators reinforced the data of Figure 2, which means that different $j$ did not show significant influence except for the test with $\mathrm{NaBr}$. In this case, the ICE and TCE values decrease significantly for $60 \mathrm{~mA} \mathrm{~cm}{ }^{-2}$, probably due to the favoring of gas evolution reaction. As expected, the increase in $j$ led to the enhancement of EC, because of the rise of the cell voltage. In addition, the best values of ICE, TCE and EC were achieved with NaF (ICE - 66.5\%, TCE - 74.5\%, EC - $23 \mathrm{kWh} \mathrm{kg}$ $\mathrm{COD}^{-1}$ for $30 \mathrm{~mA} \mathrm{~cm}{ }^{-2}$ and ICE $-67.5 \%, \mathrm{TCE}-83.1 \%, \mathrm{EC}-23.8$ $\mathrm{kWh} \mathrm{kg} \mathrm{COD}^{-1}$ for $60 \mathrm{~mA} \mathrm{~cm}^{-2}$ ).

The $\mathrm{pH}$ of the solution is a fundamental parameter in IEO, since the electrogeneration of certain oxidizing species is dependent on the $\mathrm{pH}$ medium. ${ }^{31}$ Therefore; this parameter was followed during the electrical charge passed (Figure 3), but not adjusted. Originally the $\mathrm{pH}$ of the synthetic solution was around 12.5. This value had a sharp decrease in the first $10 \mathrm{Ah} \mathrm{L}^{-1}$ of the electrochemical incineration for the different mediators. In the case of $\mathrm{NaCl}$, there was a slight drop of the $\mathrm{pH}$ from 10 to 9.3 or 9.5 until $20 \mathrm{Ah} \mathrm{L}^{-1}$ at $30 \mathrm{~mA} \mathrm{~cm}{ }^{-2}$ or $30 \mathrm{Ah} \mathrm{L}^{-1}$ at $60 \mathrm{~mA} \mathrm{~cm}^{-2}$, respectively, being the values maintained practically constant thereafter. This observation is analogous to that referred by Bonfatti et al. ${ }^{11}$ for glucose removal. The quantity of $\mathrm{NaOH}$ introduced in the system may allow carrying out the electrochemical process in better buffered media. When $\mathrm{pH}$ is at acid values, the

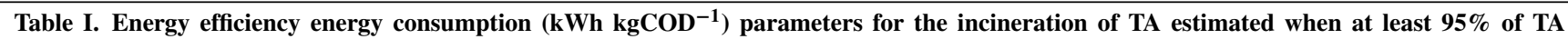
concentration was eliminated.

\begin{tabular}{|c|c|c|c|c|c|c|c|}
\hline \multirow[b]{3}{*}{ Parameters } & \multirow[b]{3}{*}{ Supporting electrolyte } & \multicolumn{6}{|c|}{ Mediators } \\
\hline & & \multicolumn{2}{|c|}{$\mathrm{NaCl}$} & \multicolumn{2}{|c|}{$\mathrm{NaBr}$} & \multicolumn{2}{|c|}{$\mathrm{NaF}$} \\
\hline & & $30 \mathrm{~mA} \mathrm{~cm}^{-2}$ & $60 \mathrm{~mA} \mathrm{~cm}{ }^{-2}$ & $30 \mathrm{~mA} \mathrm{~cm}^{-2}$ & $60 \mathrm{~mA} \mathrm{~cm}{ }^{-2}$ & $30 \mathrm{~mA} \mathrm{~cm}{ }^{-2}$ & $60 \mathrm{~mA} \mathrm{~cm}^{-2}$ \\
\hline $\operatorname{ICE}(\%)$ & 7.38 & 44.0 & 41.5 & 55.6 & 37.8 & 66.5 & 67.5 \\
\hline TCE $(\%)$ & 5.50 & 48.2 & 47.0 & 80.0 & 64.0 & 74.5 & 83.1 \\
\hline $\mathrm{EC}\left(\mathrm{kWh} \mathrm{kgCOD}^{-1}\right)$ & 207.5 & 34.5 & 44.4 & 24.1 & 33.7 & 23.0 & 23.8 \\
\hline
\end{tabular}




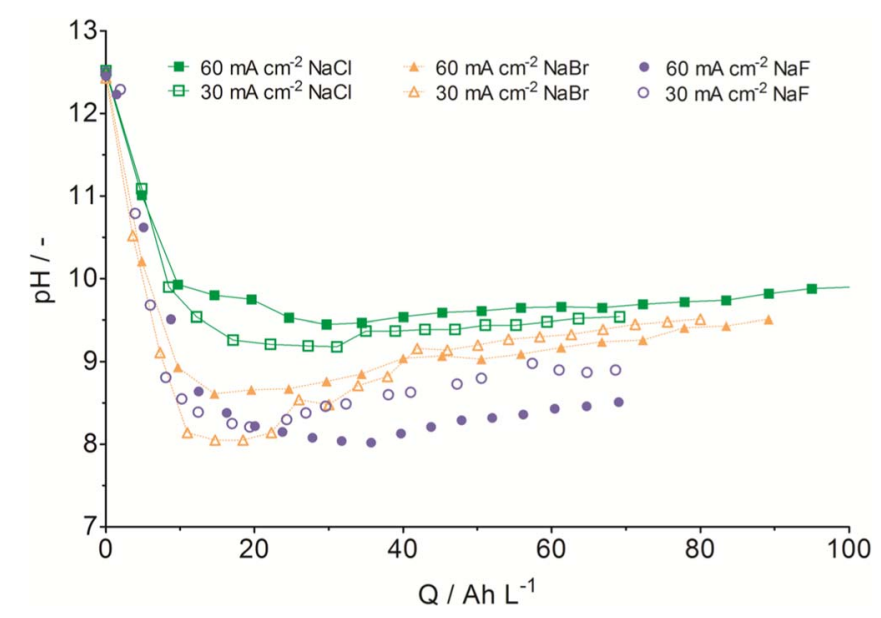

Figure 3. Evolution of $\mathrm{pH}$ as a function of specific charge passed (Q) during the incineration of TA in presence of halides applying 30 and $60 \mathrm{~mA} \mathrm{~cm}$.2. Operating condition: Supporting electrolyte $\left(0.25 \mathrm{M} \mathrm{NaOH}+0.5 \mathrm{M} \mathrm{Na}_{2} \mathrm{SO}_{4}\right)$ and $0.1 \mathrm{M}$ TA.

chloride may be loss as evolving chlorine, thus this buffering reduces its wasting as well as the chlorate production, normally formed at weakly acidic $\mathrm{pH}$, by reaction in the bulk solution between $\mathrm{HClO}$ and $\mathrm{ClO}^{-}$.

The addition of $\mathrm{NaBr}$ led to a reduction of $\mathrm{pH}$ value to $8(30 \mathrm{~mA}$ $\left.\mathrm{cm}^{-2}\right)$ and $8.5\left(60 \mathrm{~mA} \mathrm{~cm}^{-2}\right)$ until $15 \mathrm{Ah} \mathrm{L}^{-1}$. Br-based oxidants react rapidly with organic compound in solution, increasing the elimination rate and consequently, the $\mathrm{pH}$ restoration is slower. A similar trend was observed with the introduction of $\mathrm{NaF}$. However, with this mediator, no specific oxidants were formed. Only the production of acidic species, such as HF in lower concentrations, could justify the rapid decrease of $\mathrm{pH}$ conditions as well as the lower restoration of the initial $\mathrm{pH}$.

\section{Summary}

In this work, the electrochemical measurements allowed to understand the role of halide salts $(\mathrm{NaBr}, \mathrm{NaCl}$ and $\mathrm{NaF})$ in an alkaline media toward the oxygen evolution reaction given that it is in competition with the organic oxidation reaction. The concentration of halide promoted the production of active oxidants or the loss of halide from solution due to the gas evolution.

In addition, the electrochemical oxidation of TA at Pt electrodes has been explored without and with salts present in the solution. In the absence of mediators, the TOC removal rate was slower when compared to the experiments with the halogen salts. All the tests with halides led to the almost complete mineralization of the organic compounds, independently the applied $j$. It was verified that the nature of the mediators had a significant impact on the efficiency of the process, following the order: $\mathrm{Cl}^{-}\left(100-120 \mathrm{Ah} \mathrm{L}^{-1}\right)<\mathrm{Br}^{-}(80-88 \mathrm{Ah}$ $\left.\mathrm{L}^{-1}\right)<\mathrm{F}^{-}\left(55-56 \mathrm{Ah} \mathrm{L}^{-1}\right)$. Lower energy consumption was attained by the experiments with halide salts $\left(23.0-44.4 \mathrm{kWh} \mathrm{kgCOD}^{-1}\right)$ than without mediator $\left(207.5 \mathrm{kWh} \mathrm{kgCOD}^{-1}\right)$. In addition, the GC-MS analysis to the solutions revealed the formation of a small amount of organochlorinated compounds during TA incineration in presence of $\mathrm{NaCl}$, which during the process were further mineralized to $\mathrm{CO}_{2}$ and $\mathrm{H}_{2} \mathrm{O}$ or even oxidized to volatile chlorinated compounds (i.e. chloroform). Regarding, the electrochemical oxidation in presence of $\mathrm{NaBr}$ or $\mathrm{NaF}$, no organo-halide compounds were detected.

Therefore, the best experiment in terms of TOC removal and energy consumption was with $\mathrm{NaF}$ mediator.

\section{Acknowledgments}

The authors thank De Nora (Milan, Italy) for providing the electrodes. Financial support from National Council for Scientific and Technological Development (CNPq - 465571/2014-0; CNPq - 446846/2014-7 and CNPq - 401519/2014-7) and FAPESP (2014/50945-4 are gratefully acknowledged.

\section{References}

1. C. A C. . Sequeira, D. M. F. Santos, and P. S. D. Brito, Appl. Surf. Sci., 252, 6093 (2006).

2. C. A. Martínez-Huitle, M. A. Rodrigo, I. Sirés, and O. Scialdone, Chem. Rev., 115, 13362 (2015).

3. A. Anglada, A. Urtiaga, and I. Ortiz, J. Chem. Technol. Biotechnol., 84, 1747 (2009).

4. K. Jüttner, U. Galla, and H. Schmieder, Electrochim. Acta, 45, 2575 (2000).

5. D. R. da Silva, M. B. Ferreira, C. B. Nascimento, S. Ferro, C. A. Martínez-Huitle, and A. De Battisti, Current Org. Chem., 16, 1951 (2012).

6. C. A. Martinez-Huitle, S. Ferro, and A. De Battisti, Electrochem. Solid-State Lett., 8, D35 (2005).

7. R. P. Belardi and J. B. Pawliszyn, Water Pollut. Res. J. Can., 24, 179 (1989).

8. C. Comninellis and A. Nerini, J. Appl. Electrochem., 25, 23 (1995).

9. D. Rajkumar, J. G. Kim, and K. Palanivelu, Chem. Eng. Technol., 28, 98 (2005).

10. S. Tanaka, Y. Nakata, T. Rimura, Yustiawati, M. Kawasaki, and H. Kuramitz, J. Appl. Electrochem., 32, 197 (2002).

11. F. Bonfatti, S. Ferro, F. Lavezzo, M. Malacarne, G. Lodi, and A. De Battisti, J. Electrochem. Soc., 147, 592 (2000).

12. M. Panizza and G. Cerisola, Electrochim. Acta, 48, 1515 (2003).

13. C. A. Martínez-Huitle and S. Ferro, Chem. Soc. Rev., 35, 1324 (2006).

14. M. Panizza and G. Cerisola, Chem. Rev., 109, 6541 (2009).

15. E. Brillas, I. Sirés, and M. A. Oturan, Chem. Rev., 109, 6570 (2009).

16. A. B. Boscoletto, F. Gottardi, L. Milan, P. Pannocchia, V. Tartari, M. Tavan, R. Amadelli, A. De Battisti, A. Barbieri, D. Patracchini, and G. Battaglin, J. Appl. Electrochem., 24, 1852 (1994).

17. C. A. Martínez-Huitle, S. Ferro, S. Reyna, M. Cerro-López, A. De Battisti, and M. A. Quiroz, J. Braz. Chem. Soc., 19, 150 (2008).

18. M. A. El Hajj Hassan and M. M. El Jamal, Port. Electrochim. Acta, 30, 351 (2012).

19. A. M. Jirka and M. J. Carter, Anal. Chem., 47, 1397 (1975).

20. L. Vazquez-Gomez, A. De Battisti, S. Ferro, M. Cerro, S. Reyna, C. A. Martínez-Huitle, and M. A. Quiroz, Clean-Soil, Air, Water, 40, 408 (2012).

21. L. R. Czarnetzki and L. J. J. Janssen, J. Appl. Electrochem., 22, 315 (1992).

22. M. Pourbaix, Atlas d'Équilibres Électrochimiques, Gauthier-Villars, Paris (1963).

23. J. H. B. Rocha, M. M. S. Gomes, E. V. Dos Santos, E. C. M. De Moura, D. R. Da Silva, M. A. Quiroz, and C. A. Martínez-Huitle, Electrochim. Acta., 140, 438 (2014).

24. H. -J. Yan, D. Wang, M. -J. Han, L. -J. Wan, and C. -L. Bai, Langmuir, 20, 7360 (2004).

25. V. Humblot, S. Haq, C. Muryn, W. A. Hofer, and R. Raval, J. Am. Chem. Soc., 124, 503 (2002).

26. T. E. Jones and C. J. Baddeley, Surf. Sci., 513, 453 (2002).

27. O. A. Hazzazi, G. A. Attard, and P. B. Wells, J. Mol. Catal. A: Chem., 216, 247 (2004).

28. C. C. de Almeida, P. R. F. da Costa, M. J. M. Melo, E. V. dos Santos, and C. A. Martínez-Huitle, J. Mexican Chem. Soc., 58, 276 (2014).

29. D. Pletcher and F. C. Walsh, Industrial Electrochemistry, Ed. Springer Science \& Business Media (1990) 249.

30. R. M. Noyes, J. Am. Chem. Soc., 102, 4644 (1980).

31. E. Brillas and C. A. Martínez-Huitle, Appl. Catal. B, 166-167, 603 (2015). 